\title{
ESSENTIAL OIL COMPOSITION OF ARISTOLOCHIA CHILENSIS A HOST PLANT OF BATTUS POLYDAMAS
}

\author{
ALEJANDRO M URZÚA*, GASTÓN J SOTES
}

\begin{abstract}
Universidad de Santiago de chile, Facultad de Química y Biología, Departamento de Ciencias del Ambiente, Laboratorio de Química Ecológica, Universidad de Santiago de Chile, Casilla 40, Correo-33, Santiago, Chile
\end{abstract}

(Received: 17 December-Accepted: 21 January 2008)

\begin{abstract}
In this communication we report the essential oil composition of Aristolochia chilensis Bridges ex Lindl. fresh leaves. This species is one of the larval food-plants of Battus polydamas Boisd., the only butterfly of the family Papilionidae (Lepidoptera) occurring in Chile. In order to determine possible chemical similarities among several of its host species distributed throughout the continent, we compared these results with data obtained from literature on the composition of other representative Aristolochia species occurring in Argentina, Paraguay, and Brazil. Instead of the expected, it was found that the essential oil of each species considered in this work exhibits a particular characteristic profile.
\end{abstract}

Keywords: Aristolochia chilensis; Aristolochiaceae; monoterpenes; sesquiterpenes; Battus polydamas

\section{INTRODUCTION}

Two species represent the family Aristolochiaceae in Chile, Aristolochia chilensis Bridges ex Lindl., and Aristolochia bridgesii (Klotzsch) Duch. The former is a summer-deciduous low creeping herb ranging southwards from Caldera in Northern Chile $\left(27^{\circ} \mathrm{S}\right)$ to beyond the latitude of Santiago $\left(34^{\circ} \mathrm{S}\right)$, and known by the local names of "oreja de zorro" (fox ear) and "hierba de la Virgen María" (Virgin Mary's herb)'. Also, A. chilensis is one of the larval food-species of Battus polydamas Boisd. the only butterfly of the family Papilionidae (Lepidoptera) occurring in Chile ${ }^{2,3}$. Previous investigations of A. chilensis revealed the presence of aristolochic acids, 4,5-dioxoaporphines and aristolactams in its aerial parts ${ }^{4-6}$, and lignans as well as sesquiterpene hydrocarbons in its roots 7,8

The essential oil of $A$. chilensis has not been previously studied, and the role of its volatile components in the recognition of this species as a host by the butterfly B. polydamas is not known. In this communication we report the essential oil composition of $A$. chilensis fresh leaves. We also compare these results with data obtained from literature on the composition of other seven Aristolochia species, distributed throughout the continent and representative to this work as they are all hosts of populations of $B$. polydamas ${ }^{2}$ occurring in their distribution area. The selected species were: A. cymbifera, A.giganteae, A.macroura, and A.triangularis ${ }^{9}$, from Brasil; A. argentina ${ }^{10}, A$. gibertii ${ }^{11}$ and $A$. elegans ${ }^{12}$, from Argentina; and again $A$. gibertii ${ }^{13}$ from Paraguay. The purpose of this comparison was to determine possible chemical similarities among the essential oil of several host species of $B$. polydamas occurring in significantly different environments and, perhaps, elucidate common molecular candidates to host-recognition and host-acceptation kairomones for this butterfly ${ }^{14}$.

\section{Plant Material}

Leaves of Aristolochia chilensis Miers Bridges ex Lindl. were collected in December of 2005 in Cuesta Lo Prado (Lo Prado Pass), Region Metropolitana, Chile $\left(33^{\circ} 10^{\prime} \mathrm{S}, 70^{\circ} \mathrm{W}\right)$. Voucher specimens (SGO-077867) were deposited in the Herbarium of the National Museum of Natural History, Santiago, Chile.

\section{Analysis of the Constituents}

The essential oil of Aristolochia chilensis was obtained by steam distillation of fresh leaves $(500 \mathrm{~g})$ for $4-5$ hours yielding an oily extract $(250 \mathrm{mg})$. The essential oil was analyzed by GC-MS using a Hewlett Packard 5890 (series II) gas chromatograph linked to a HP-5972 mass-selective detector and to the NIST (1998) library. Separation was performed using a SPB- 5 column $(30 \mathrm{~m} \times 0.25 \mathrm{~mm}$ × $0.25 \mu \mathrm{m}$ film thickness, Supelco Inc., Bellefonte, PA). The initial temperature was $35^{\circ} \mathrm{C}(5 \mathrm{~min})$ followed by a rise to $260^{\circ} \mathrm{C}$ at a rate of $5^{\circ} \mathrm{C} / \mathrm{min}$. Then it was kept isothermally for $5 \mathrm{~min}$. Helium was the carrier gas at a flow rate of $1 \mathrm{ml} / \mathrm{min}$. The temperature of the injector and detector was $270^{\circ} \mathrm{C}$.

\section{Identification of the compounds}

The identification of the compounds in the chromatographic profiles was achieved by comparison of their mass spectra with a library data base (NIST 1998) using a reverse search technique which verified that main peaks in the reference spectrum were present in the unknown spectrum ${ }^{15}$. Spectra were considered coincident if the similarity index was higher than $95 \%$. Preliminary identifications were confirmed by the observation of peak enhancements upon co-injection of standards: linalool, 1,8-cineol, $\alpha$-cubebene, $\alpha$-humulene, and alloaromadendrene, obtained from Aldrich-Sigma USA, and $\beta$-elemene, $\beta$ caryophyllene, $\alpha$-himachalene, and $\Delta^{1(10)}$-aristolene, all previously identified compounds in roots of $A$. chilensis $^{8}$. When standards were not available, mass spectra were compared with published spectrometric data ${ }^{8,15-17}$. Also, Kovats index of the peaks were compared with values from the literature ${ }^{15-17}$.

\section{RESULTS AND DISCUSSION}

A total of 30 compounds were identified (Table 1), constituting $83.7 \%$ of total essential oil of Aristolochia chilensis. Mainly sesquiterpenes were found $(81.1 \%)$ and very low contents of monoterpenes $(0.7 \%)$ and miscellaneous compounds (1.9\%).

Table 1. Essential oil components from leaves of Aristolochia chilensis

\begin{tabular}{|l|c|c|}
\hline Components & $(\mathbf{\%})^{\mathbf{a}}$ & RI \\
\hline Monoterpenes & & \\
\hline 1,8 -cineole & Tr. & 1034 \\
\hline linalool & $0.3(0.001)$ & 1087 \\
\hline 4-terpineol & $0.4(0.002)$ & 1184 \\
\hline Sesquiterpenes & & \\
\hline$\beta$-bourbonene & $1.2(0.004)$ & 1386 \\
\hline$\beta$-elemene & $0.2(0.001)$ & 1389 \\
\hline isocaryophyllene & $20.8(1.25)$ & 1403 \\
\hline$\alpha$-gurjunene & $0.6(0.002)$ & 1411 \\
\hline$\beta$-caryophyllene & $13.5(1.0)$ & 1419 \\
\hline$\alpha$-himachalene & $0.5(0.002)$ & 1445 \\
\hline$\alpha$-humulene & $2.8(0.01)$ & 1450 \\
\hline$\Delta^{1(10)}$-aristolene & $6.5(0.02)$ & 1453 \\
\hline allo-aromadendrene & $1.1(0.003)$ & 1466 \\
\hline germacrene D & 0.1 & 1475 \\
\hline$\alpha$-curcumene & $1.7(0.005)$ & 1483 \\
\hline$\gamma$-elemene & $0.5(0.003)$ & 1495 \\
\hline$\gamma$-selinene & 0.1 & 1498 \\
\hline$\gamma$-cadinene & $0.3(0.001)$ & 1504 \\
\hline$\alpha$-farnesene & $8.4(0.03)$ & 1505 \\
\hline$\delta$-cadinene & $3.5(0.01)$ & 1515 \\
\hline$\beta$-cadinene & $0.6(0.002)$ & 1519 \\
\hline$\beta$-cubebene & 0.2 & 1536 \\
\hline $3,7(11)$-selinadiene & 0.2 & 1542 \\
\hline$E$-nerolidol & $1.4(0.003)$ & 1561 \\
\hline caryophyllene oxide & $12.9(0.05)$ & 1571 \\
\hline$\alpha$-cadinol & $1.1(0.002)$ & 1619 \\
\hline Farnesol & $1.6(0.003)$ & 1652 \\
\hline$\alpha$-bisabolol & $1.3(0.002)$ & 1682 \\
\hline Miscellaneous compounds & $1.9(0.004)$ & \\
\hline & & \\
\hline & & \\
\hline & & \\
\hline
\end{tabular}

RI, retention indices; ' Peak area of identified compounds; mean of three independent analysis (SD in parenthesis); tr, trace amounts $<0.05 \%$

The components of the essential oils of $A$. chilensis and of A.cymbifera, A.giganteae, A.macroura, A.triangularis ${ }^{9}$, A. argentina ${ }^{10}$, A. gibertii ${ }^{11,13}$ and A. elegans ${ }^{12}$ are shown in Table 2. In all the cases consulted from literature, the essential oil had also been obtained from the leaves of the corresponding species and by means of a similar methodology used in this work. This factor was taken into account in the choice of literature data for comparison in order to minimize the composition variation attributable to plant tissues and dissimilar extraction and fractioning techniques. 
Table 2. Composition of the essential oils of A. chilensis and seven other Aristolochia species, obtained by steam distillation of leaves.

\begin{tabular}{|c|c|c|c|c|c|c|c|c|c|}
\hline & A.ch & A.cy & A.gig & A.ma & A.tr & A.arg & A.gP & A.gA & A.ele \\
\hline Monoterpenes & 0.7 & - & - & 10.7 & 7.3 & 1.0 & 0.6 & 1.5 & - \\
\hline \multicolumn{10}{|l|}{$\begin{array}{l}\text { Sesquiterpenes } \\
\text { Farnesanes }\end{array}$} \\
\hline$\alpha$-farnesene & 8.4 & 5.6 & - & - & - & - & - & - & - \\
\hline$\beta$-farnesene & - & - & - & - & - & 1.9 & 3.6 & - & - \\
\hline farnesol & 1.6 & - & - & - & - & - & - & - & - \\
\hline$E$-nerolidol & 1.4 & - & - & 33.1 & 12.3 & - & 17.5 & 0.1 & 0.5 \\
\hline farnesyl ketone & - & - & - & - & - & - & - & - & 0.2 \\
\hline \multicolumn{10}{|l|}{ Bisabolanes } \\
\hline$\beta$-bisabolene & - & - & - & - & - & - & 0.2 & - & - \\
\hline$\alpha$-curcumene & 1.7 & - & - & - & - & - & - & - & $\operatorname{tr}$ \\
\hline$\alpha$-bisabolol & 1.3 & - & - & - & - & - & - & - & - \\
\hline$\beta$-sesquiphellandrene & - & - & - & - & - & - & 4.0 & - & - \\
\hline \multicolumn{10}{|l|}{ Elemanes } \\
\hline$\beta$-elemene & 0.2 & - & 1.2 & - & 1.7 & 0.1 & 2.1 & 2.7 & 1.2 \\
\hline$\gamma$-elemene & 0.5 & - & 21.6 & 12.8 & 9.1 & - & - & - & - \\
\hline$\delta$-elemene & - & - & - & 2.9 & - & 0.6 & 1.0 & 1.1 & 1.1 \\
\hline \multicolumn{10}{|l|}{ Germacranes } \\
\hline germacrene A & - & 3.2 & 3.5 & - & - & - & - & - & - \\
\hline germacrene B & - & - & - & - & - & - & 0.4 & - & 1.0 \\
\hline germacrene D & 0.1 & - & 24.9 & - & 4.8 & 2.7 & 8.5 & 5.8 & 12.7 \\
\hline aristolactone & - & - & - & - & - & - & - & 9.9 & - \\
\hline \multicolumn{10}{|l|}{ Bicyclogermacranes } \\
\hline bicyclogermacrene & - & - & - & - & - & 8.4 & 26.8 & 38.1 & 32.4 \\
\hline \multicolumn{10}{|l|}{ Humulanes } \\
\hline$\alpha$-humulene & 2.8 & - & 7.3 & 15.5 & 2.5 & 0.3 & - & $\operatorname{tr}$ & 2.6 \\
\hline \multicolumn{10}{|l|}{ Aristolanes } \\
\hline$\Delta^{\mathrm{I}(10)}$-aristolene & 6.5 & - & - & - & - & $\mathrm{Tr}$ & 0.7 & - & - \\
\hline \multicolumn{10}{|l|}{ Caryophyllanes } \\
\hline B-caryophyllene & 13.5 & 6.6 & 12.7 & 10.6 & 4.8 & 5.5 & 3.4 & 2.2 & 27.8 \\
\hline isocaryophyllene & 20.8 & - & - & - & - & - & - & - & 0.6 \\
\hline caryophyllene oxide & 12.9 & - & - & - & - & - & - & - & 0.9 \\
\hline \multicolumn{10}{|l|}{ Eudesmanes } \\
\hline$\gamma$-selinene & 0.1 & - & - & - & - & - & - & - & - \\
\hline $3,7(11)$-selinadiene & 0.2 & - & - & - & - & - & - & - & - \\
\hline \multicolumn{10}{|l|}{ Cadinanes } \\
\hline$\beta$-cadinene & 0.6 & - & - & - & - & - & - & - & - \\
\hline$\delta$-cadinene & 3.5 & - & 7.1 & 5.3 & 5.6 & - & 1.5 & - & 0.1 \\
\hline$\gamma$-cadinene & 0.3 & - & - & - & 9.2 & - & 0.5 & 0.9 & 2.4 \\
\hline$\gamma$-muurolene & - & - & - & - & - & - & 1.0 & - & - \\
\hline$\alpha$-cadinol & 1.1 & - & 0.9 & 3.1 & 3.3 & - & 0.5 & - & 1.0 \\
\hline cubenol & - & - & - & - & - & - & - & - & 0.1 \\
\hline epi-cubenol & - & - & - & - & - & - & - & - & 0.2 \\
\hline$\tau$-cadinol & - & - & - & - & - & - & - & - & 0.2 \\
\hline$\tau$-muurolol & - & - & - & - & - & - & - & - & 0.5 \\
\hline Guaianes & & & & & & & & & \\
\hline$\delta$-guaiene & - & - & - & - & - & - & 1.3 & - & - \\
\hline Aromadendranes & & & & & & & & & \\
\hline aromadendrene & - & - & - & - & - & - & - & 4.5 & - \\
\hline allo-aromadendrene & 1.1 & - & - & - & - & - & - & $\operatorname{tr}$ & 0.2 \\
\hline$\alpha$-gurjunene & 0.6 & - & - & - & - & - & - & - & 0.4 \\
\hline ledene & - & - & - & - & - & - & 1.3 & - & - \\
\hline globulol & - & - & - & - & - & - & 0.6 & - & 0.4 \\
\hline viridiflorol & - & - & - & - & - & - & - & - & 0.3 \\
\hline spathulenol & - & - & - & - & - & 3.5 & 3.4 & 12.8 & 1.9 \\
\hline Cubebanes & & & & & & & & & \\
\hline$\alpha$-cubebene & - & 0.7 & - & - & 1.3 & - & - & - & 0.2 \\
\hline$\beta$-cubebene & 0.2 & - & - & - & - & - & - & - & 0.2 \\
\hline Himachalanes & & & & & & & & & \\
\hline$\alpha$-himachalene & 0.5 & - & - & - & - & - & 0.7 & - & - \\
\hline Santalanes & & & & & & & & & \\
\hline$\alpha$-trans-bergamotene & - & 2.4 & 2.3 & - & - & 1.1 & 0.4 & - & - \\
\hline Copaanes & & & & & & & & & \\
\hline$\alpha$-copaene & - & 4.6 & 8.6 & 2.5 & 4.7 & 0.1 & 0.4 & 0.3 & 1.1 \\
\hline Bourbonanes & & & & & & & & & \\
\hline$\beta$-bourbonene & 1.2 & 2.1 & 3.1 & - & - & 0.2 & 0.8 & 0.5 & 1.1 \\
\hline Miscellaneous compounds & 1.9 & - & - & - & - & 58.8 & - & - & - \\
\hline Aliphatic hydrocarbons & - & 52.1 & - & - & 15.3 & - & - & - & - \\
\hline
\end{tabular}

A.ch- A. chilensis; A.cy- A. cymbifera; A.gig- A. gigantea; A.ma- A. macroura; A.tr- A. triangularis; A.arg- A. argentina; A.gP- A. gibertti from Paraguay; A.gA- $A$. gibertti from Argentina; A.ele- A. elegans; tr: traces $(<0.05 \%)$. 
The considered essential oils are quite diverse among them when reported compounds and their biosynthetic paths are both taken into account. The essential oil of $A$. chilensis is rich in caryophyllanes: $\beta$-caryophyllene (1), isocaryophyllene (2), and caryophyllene oxide (3). These three compounds together with $\alpha$-farnesene (4) and $\Delta^{1(10)}$-aristolene (5) represent a $77 \%$ of the total identified sesquiterpenes in this species. Isocaryophyllene (2) is a very uncommon compound in the other Aristolochia species ${ }^{18}$ while $\Delta^{1(10)}$-aristolene (5) can only be found only in trace amounts in A. argentina and A. gibertii from Paraguay.

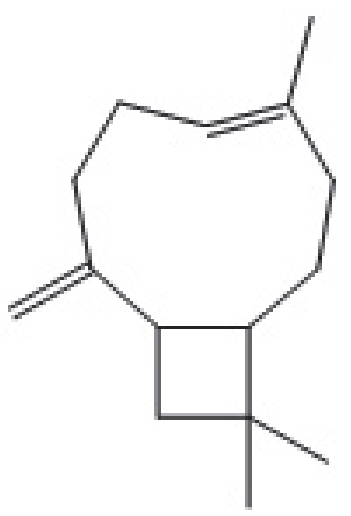

1

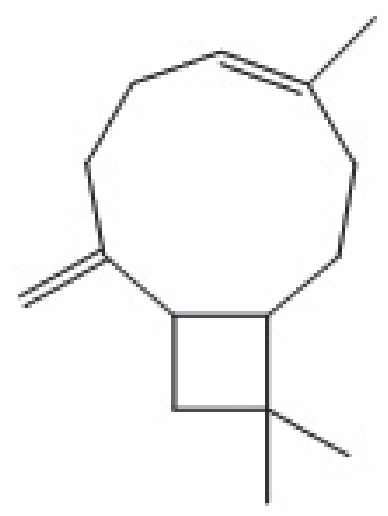

2

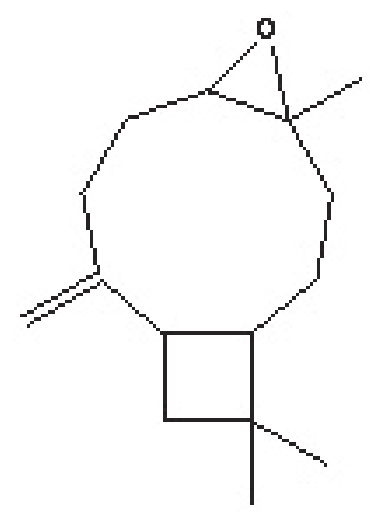

3

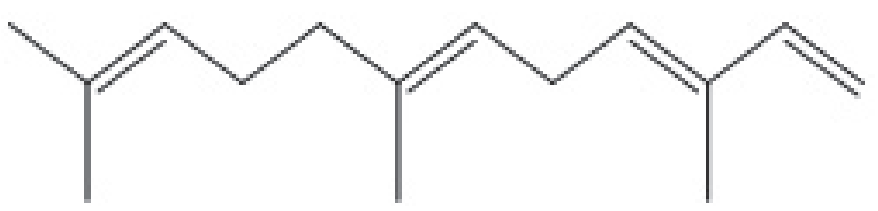

4

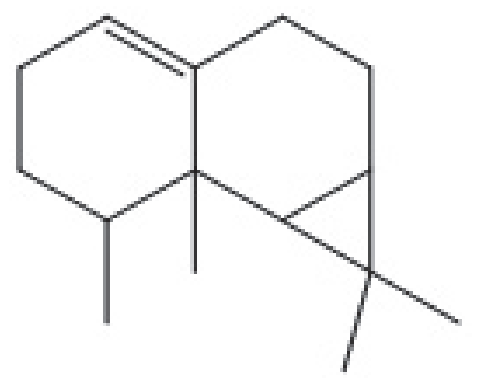

5
Bicyclogermacrene (bicyclogermacranes) is a predominant compound in A. elegans ${ }^{12}$, A. gibertii ${ }^{11,13}$, and A. argentina ${ }^{10}$, although it was not found in the essential oil of the other species ${ }^{18}$. In addition, the essential oil of $A$. gibertii from Argentina exhibits a $9.9 \%$ of aristolactone ${ }^{11}$, a compound biosynthesized from germacrene A by means of a sequence of oxidation reactions. In the case of $A$. argentina, its leaves show high levels of argentilactone (57.5-59.5\%) and undecatrienes, non terpenoid compounds unique to this species ${ }^{10}$. The presence and quantitative prevalence of the previous over all other components is a most relevant and distinctive chemical characteristic of the essential oil of A. argentina.

All these essential oils are composed by a majority of sesquiterpenes compounds, belonging to a total of seventeen biosynthetic families ${ }^{19}$, except for A. cymbifera which contains a $52.1 \%$ of a mixture of aliphatic hydrocarbons (nonane, 1-undecene, decane, undecane and dodecane). Also, A. triangularis contains a relative high amount of decane and dodecane $(15.3 \%)^{9}$. Concerning monoterpenoids, shown in minute amounts as a general tendency in these essential oils, linalool (10.7\%) and $p$-cymene (7.3\%) were found respectively in $A$. macroura and A. triangularis ${ }^{9}$.

In conclusion, species of the Aristolochia genus from different habitats, but equivalent as to the characteristic of hosting Battus polydamas, show particular biosynthetic characteristics. The absence of a strikingly common chemical feature among these essential oils contrasted with the expectation of recognizing, among the bouquet of volatile compounds, molecular candidates to common host-recognition and host-acceptation kairomones for the butterfly. Considering the distribution of the chosen species in distant geographic areas, it is possible that each population of butterflies has developed the ability of recognizing specifically the Aristolochia species of its own territory by means of detecting the characteristic combination of volatile compounds acting as host habitat-location and as host-recognition kairomones ${ }^{14}$ in each case.

\section{ACKNOWLEDGEMENTS}

This work was supported by FONDECYT, Grant N 1060033-2006.

\section{REFERENCES}

1. L. E. Navas, Flora de la Cuenca de Santiago 2. Ed. Universidad de Chile, Santiago, 1976.

2. K. L. Silva-Brandão, A.V.L. Freitas, A.V.Z. Broker, V. N. Solferini, Mol. Phylogenet. Evol. 36, 468, (2005)

3. A. Urzúa, H. A. Priestap, Biochem. Syst. Ecol.13, 169, (1985)

4. A. Urzúa, A. J. Freyer, M. Shamma, J. Nat. Prod. 50, 305, (1987)

5. A. Urzúa, R. Rodríguez, B. Cassels, Biochem. Syst. Ecol. 15, 687, (1987)

6. A. Urzúa, V. Rojas, Fitoterapia, 61,190, (1990)

7. A. Urzúa, L. Presle, Phytochemistry, 34, 874, (1993)

8. A. Urzúa, R. Rodríguez, Bol. Soc. Chil. Quím. 37, 183, (1992)

9. G. G. Leitão, D. Lopez, F. de Sousa Menezes, M. A. C. Kaplan, A. A. Craveiro, J. W. Alentar, J. Essential Oils Res. 3, 403, (1991)

10. Priestap, H.A., van Baren, C. M., Di Leo Lira, P., Coussio, J.D., Bandoni, A.L., Phytochemistry, 63, 221, (2003)

11. H. A. Priestap, C. M. van Baren, P. Di Leo Lira, H. J. Prado, M. Neugebauer, R. Mayer, A. L. Bandoni, Flavour Fragr. J. 17, 69, (2002)

12. R. Vila, M. Mundina, L. Muschietti, H. A. Priestap, A. L. Bandoni, T. Adzet, S. Cañigueral, Phvtochemistry, 46, 1127, (1997)

13. N. Canela, E. Ferro, N. Alvarenga, R. Vila, S. Cañigueral, J. Essential Oils Res. 16, 566, (2004)

14. J. Ruther, Meiners, T., Steidle, J.L.M., Chemoecology, 12, 161, (2002)

15. A. A. Swingar, R. M. Silverstein, 1981. Monoterpenes Infrared, Mass, ${ }^{1} \mathrm{H}$ NMR, and ${ }^{13} \mathrm{C}$ NMR Spectra, and Kováts Indices. Aldrich Chemical Company, Inc. Milwaukee, USA, 1981.

16. A. Urzúa, R. Santander, J. Echeverría, M. C. Rezende, J. Chil. Chem. Soc. 52, 1142, (2007)

17. P. R. Adams, Identification of Essential Oil Components by Gas Chromatography/Mass Spectromety, $4^{\text {th }}$. Ed. Allured Publishing Corp. Illinois USA, 2007.

18. T-S. Wu, A. G. Damu, C-R. Su, P-C. Kuo, Nat. Prod. Rep. 21, 594, (2004)

19. J. D. Connolly, R. A.Hill, Dictionary of Terpenoids vol. I. Mono and Sesquiterpenoids, Chapman and Hall, London, 1992. 